\title{
Stimulation of a non-functioning pituitary macroadenoma after administration of goserelin acetate for locally advanced prostate cancer causing a sustained elevation in PSA and testosterone
}

\author{
Fady R. Youssef, MD; Robert T. Robinson, MD; Nigel R. Boucher, MD* \\ *Department of Urology, Chesterfield Royal Hospital, Chesterfield, UK; †Department of Endocrinology, Chesterfield Royal Hospital, Chesterfield, UK
}

Cite as: Can Urol Assoc J 2012;6(2):e84-86. hittp://dx.doi.org/10.5489/cuaj.11126

\begin{abstract}
Long-acting luteinizing hormone-releasing hormone (LHRH) agonists, such as goserelin, have been used for locally advanced and metastatic prostate cancer for many years and are the main forms of androgen deprivation therapy (ADT). Acting on pituitary LHRH receptors, they initially stimulate a transient rise in serum folliclestimulating hormone (FSH) and LH. Long-term administration of an $\mathrm{LHRH}$ analogue will eventually lead to down regulation of $\mathrm{LHRH}$ receptors, thus suppressing FSH and $\mathrm{LH}$ secretion. This in turn suppresses testosterone production hence achieving and maintaining androgen deprivation. This case highlights the potential anomaly of a sustained elevated serum testosterone in the context of newly diagnosed locally advanced prostate cancer with a co-existing pituitary macroadenoma after administration of LHRH analogues. Alternative methods of androgen deprivation must be considered in such patients.
\end{abstract}

\section{Introduction}

Long-acting luteinizing hormone-releasing hormone (LHRH) agonists, such as goserelin, have been used for locally advanced and metastatic prostate cancer for many years and are the main forms of androgen deprivation therapy (ADT). Acting on pituitary LHRH receptors, they initially stimulate a transient rise in serum follicle-stimulating hormone (FSH) and LH. Long-term administration of an LHRH analogue will eventually lead to down regulation of $\mathrm{LHRH}$ receptors, thus suppressing $\mathrm{FSH}$ and $\mathrm{LH}$ secretion. This in turn suppresses testosterone production hence achieving and maintaining androgen deprivation.

\section{Case report}

A 75-year-old man was admitted to hospital with a one and a half week history of dizziness and weight loss. He had significant postural hypotension, with serum sodium of $115 \mathrm{mmol} / \mathrm{L}$ (range: 135-145) with normal renal function. A short synacthen test was suboptimal, and he was started on replacement therapy with hydrocortisone. Serum testosterone was at the low end of normal at $7.3 \mathrm{nmol} / \mathrm{L}$ (range: $7-18$ ) and prolactin slightly elevated at $476 \mathrm{mU} / \mathrm{L}$ (range: 0-456). Thyroid function, insulin-like growth factor (IGF)-1 and gonadotrophins were normal. Subsequent pituitary magnetic resonance imaging demonstrated a $34 \times 27 \times 24 \mathrm{~mm}$ pituitary macroadenoma. The tumour partially encased the carotids, and compressed the optic chiasm. There was no significant visual disturbance. Neurosurgical opinion was to opt for a conservative approach with visual field monitoring.

The patient was kept under regular review, and described feeling marvellous on hydrocortisone. His other pituitary function remained stable, with testosterone levels at the lower end of normal. Two years after initial presentation, he complained of erectile difficulties. A repeat 9 am testosterone at this time was low at $5.6 \mathrm{nmol} / \mathrm{L}$ and testosterone replacement was discussed. Prostate-specific antigen (PSA) level was $3.9 \mathrm{ng} / \mathrm{mL}(<6.5)$, and digital rectal examination (DRE) revealed a benign-feeling prostate. He started topical testosterone gel supplementation at a dose of $50 \mathrm{mg}$ daily. Three months later, he was reviewed in clinic, and admitted having stopped the testosterone after one month because he felt it had made little difference to his well-being. One year later, his serum testosterone had dropped further to $2.6 \mathrm{nmol} / \mathrm{L}$ and he complained of tiredness. Thyroid function continued to be normal. A further trial of testosterone was discussed and the patient consented. He started on $60 \mathrm{mg}$ of testosterone gel daily.

Three months later he came to clinic, and felt he had more energy since starting testosterone. His PSA, though, had risen significantly to $12.2 \mathrm{ng} / \mathrm{mL}$. Testosterone was stopped and he was referred urgently to a urologist.

Repeat DRE revealed locally advanced prostate cancer, clinically T3. Transrectal prostate biopsies confirmed a moderately differentiated adenocarcinoma of the prostate (Gleason score $4+3=7$ ). Following cessation of testoster- 
one therapy, his PSA and random serum testosterone were $7.3 \mathrm{ng} / \mathrm{L}$ and $4.6 \mathrm{nmol} / \mathrm{mL}$, respectively. He started medical ADT in the form of the anti-androgen cyproterone acetate initially, with subsequent monthly preparations of the gonadorelin analogue goserelin acetate $3.6 \mathrm{mg}$ injections.

Three months later, repeat PSA was $12.2 \mathrm{ng} / \mathrm{mL}$, and random serum testosterone was $15.8 \mathrm{nmol} / \mathrm{L}$. These had both risen significantly since the diagnosis of prostate cancer and the start of treatment. This suggested the goserelin acetate was stimulating $\mathrm{FSH}$ and $\mathrm{LH}$ secretion from his previously non-functioning pituitary macroadenoma. His FSH levels were elevated at $22.3 \mathrm{U} / \mathrm{L}(<9 \mathrm{U} / \mathrm{L})$ and $\mathrm{LH}$ levels were also elevated at $10.9 \mathrm{U} / \mathrm{L}(<9 \mathrm{U} / \mathrm{L})$. Prior to treatment with goserelin acetate, his gonadotrophins had been consistently in the normal range. Serum testosterone at this point had also continued to rise to $17.8 \mathrm{nmols} / \mathrm{L}$.

The goserelin acetate was stopped and a bilateral subcapsular orchidectomy was performed. One month following this, serum testosterone was $<0.4 \mathrm{nmol} / \mathrm{L}$ confirming that androgen deprivation had been achieved.

\section{Discussion}

Long-acting LHRH agonists, such as goserelin, have been used for locally advanced and metastatic prostate cancer for many years and are the main forms of ADT., ${ }^{1,2}$ They are synthetic analogues of LHRH and are given as depot injections on a 1, 3 or 6 monthly basis. Acting on pituitary LHRH receptors, they initially stimulate a transient rise in serum FSH and $\mathrm{LH}$. This leads to a temporary rise in serum testosterone or "testosterone surge." This begins in the first 2 to 3 days and lasts for about 1 week following the first injection. ${ }^{3}$ To avoid clinical flares associated with this testosterone surge (i.e., namely bone pain, acute bladder outlet obstruction, obstructive renal failure and spinal cord compression), concomitant anti-androgen therapy is administered. The most common anti-androgen used is cyproterone acetate $100 \mathrm{mg}$ three times daily, which is usually started 1 week prior to the first LHRH injection and continued for 2 weeks thereafter.

Long-term administration of an LHRH analogue will eventually lead to down regulation of LHRH receptors, thus suppressing FSH and LH secretion. This in turn suppresses testosterone production hence achieving and maintaining androgen deprivation. Hormone castrate levels are usually achieved within 2 to 4 weeks. ${ }^{4,5}$ Seidenfeld and colleagues stated in a meta-analysis that single therapy ADT in the form of LHRH analogues for advanced prostate cancer had similar efficacy to orchidectomy in achieving androgen deprivation levels. ${ }^{6}$ In rare cases $(10 \%)$, some individuals fail to achieve serum testosterone values within the castration range during treatment with LHRH analogues. ${ }^{7}$ Specific causes have been reported, such as reactions at the depot injection site, thought to represent granulomatous reactions to leupoprolein acetate induced by the biodegradable nature of the microcapsules. ${ }^{8,9}$

This case describes a patient with a non-functioning pituitary macroadenoma, who had secondary hypogonadism and hypoadrenalism. Locally advanced prostate cancer was detected 18 to 24 months after the start of testosterone supplementation. Controversy exists regarding testosterone supplementation and whether increasing serum testosterone above a threshold has a causative effect in prostate cancer. Recent evidence has suggested this does not have a negative impact on prostate cancer progression. ${ }^{10,11}$ The initial treatment plan was to use the LHRH analogue, goserelin acetate. However, with this treatment serum testosterone rose unexpectedly to $15.8 \mathrm{nmol} / \mathrm{L}$ and continued to rise to $17.8 \mathrm{nmol} / \mathrm{L}$ after 3 months. At this time, we would expect treatment with an LHRH analogue to have achieved androgen deprived levels of serum testosterone. This was associated with a rise in $\mathrm{FSH}$ and $\mathrm{LH}$ levels suggesting the LHRH analogues had stimulated further production of gonadotrophins and thus the normal process of down-regulation had not occurred. Consequently, there was a sustained rise in the serum testosterone levels. Bilateral scrotal orchidectomy was then successful in achieving castrate levels of serum testosterone.

\section{Conclusion}

This interesting case highlights the potential anomaly of a sustained elevated serum testosterone in the context of newly diagnosed locally advanced prostate cancer with a co-existing pituitary macroadenoma after administration of $\mathrm{LHRH}$ analogues. Alternative methods of hormone castration must be considered in such patients.

Competing interests: None declared.

This paper has been peer-reviewed.

\section{References}

1. Mcleod DG. Hormonal therapy: historical perspective to future directions. Urology 2003;61 (2 Suppl 1):3-7. http://dx.doi.org/10.1016/S0090-4295(02)02393-2

2. Oefelein MG, Resnick MI. Effective testosterone suppression for patients with prostate cancer: is there a best castration? Urology 2003;62:207-13. http://dx.doi.org/10.1016/S0090-4295(03)00331-5

3. Agarwal DK, Costello AJ, Peters J, et al. Differential response of prostate specific antigen to testosterone surge after luteinizing hormone-releasing hormone analogue in prostate cancer and benign prostatic hyperplasia. BJU Int 2000;85:690-5.

4. Luteinizing hormone-releasing hormone analogs: their impact on the control of tumorigenesis. Schally AV. Peptides 1999;20:1247-62. http://dx.doi.org/10.1016/S0196-9781 (99)00130-8

5. LHRH analogues as anticancer agents: pituitary and extrapituitary sites of action. Limonta $P$, Montagnani Marelli M, Moretti RM. Expert Opin Investig Drugs 2001;10:709-20. http://dx.doi. org/10.1517/13543784.10.4.709

6. Seidenfeld J, Samson DJ, Hasselblad V, et al. Single-therapy androgen suppression in men with advanced prostate cancer: a systematic review and meta-analysis. Ann Intern Med 2000;132:566-77. 
Youssef et al.

7. Yri OE, Bioro T, Fossa SD. Failure to achieve castration levels in patients using leuprolide acetate in locally advanced prostate cancer. Eur Urol 2006;49:54-8. http://dx.doi.org/10.1016/i.eururo.2005.09.009

8. Koupparis AJ, Tyrrell C. Non-suppression of testosterone in patients with a rising prostate-specific antigen level receiving luteinising hormone-releasing hormone analogues for metastatic prostate cancer. Clin Oncol 2006; 18:571-2. http://dx.doi.org/10.1016/i.clon.2006.04.001

9. Yasukawa K, Sawamura D, Sugawara $\mathrm{H}$, et al. Leupoprolein acetate granulomas: case reports and review of the literature. Br J Dermatol 2005;152:1045-7.

10. Goldenberg SL, Koupparis A, Robinson ME. Differing levels of testosterone and the prostate: a physiological interplay. Nat Rev Urol 2011;8:365-77. http://dx.doi.org/10.1038/nrurol.2011.79
11. Morgentaler A, Traish AM. Shifting the paradigm of testosterone and prostate cancer: the saturation model and the limits of androgen-dependent growth. Eur Urol 2009;55:310-20. http://dx.doi.org/10.1016/i.eururo.2008.09.024

Correspondence: Mr. Fady R. Youssef, Specialty Registrar, Department of Urology, Royal Hallamshire Hospital, Glossop Road, Sheffield, S10 2JF. UK; fyoussef@gmail.com 